
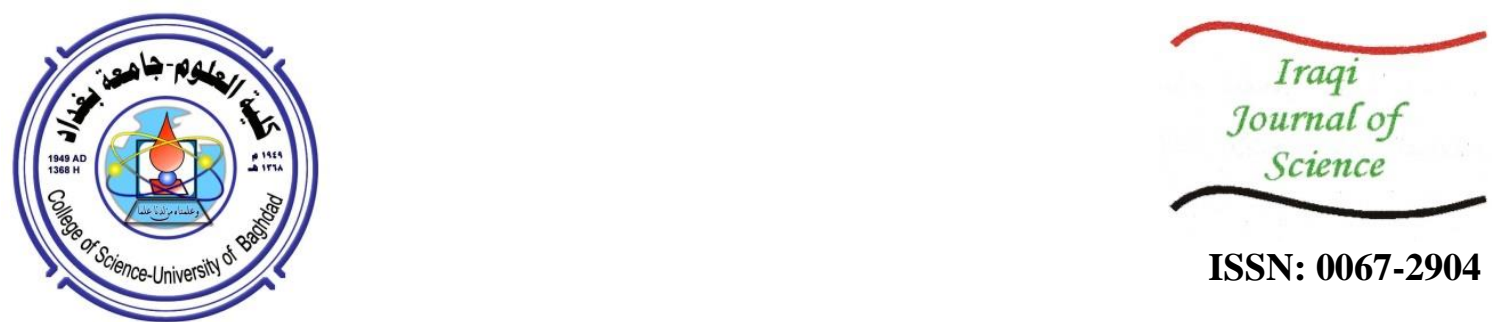

ISSN: 0067-2904

\title{
Characteristics of the Oil Water Contact Zone of Nhar Umr and Mishrif Reservoirs in Kumait and Dujaila Oil Fields, Southern Iraq, Using Vp/Vs Ratio and Porosity Logs Data
}

\author{
Nowfal A. Nassir ${ }^{* 1}$, Ahmed S. Al-Banna ${ }^{1}$, Ghazi H. Al-Sharaa ${ }^{2}$ \\ ${ }^{1}$ Department of Geology, College of Science, University of Baghdad, Baghdad, Iraq \\ ${ }^{2}$ Oil Exploration Company, Baghdad, Iraq. \\ Received: 21/12/2019 \\ Accepted: 30/1/2020

\begin{abstract}
The detailed data of the $\mathrm{Vp} / \mathrm{Vs}$ ratio and porosity logs were used to detect the Oil-Water Contact Zone (OWCZ) of Nahr Umr sandstone and Mishrif limestone reservoir formations in Kumiat $(\mathrm{Kt})$ and Dujaila $(\mathrm{Du})$ oil fields, southeastern Iraq. The results of OWC were confirmed using P-wave, Resistivity, and Water Saturation $(\mathrm{Sw}) \operatorname{logs}$ of Kt-1 and Du-1 wells. It was found that the values of the oilwater contact zone thickness in Nahr Umr sandstone and Mishrif limestone were approximately one meter and eight meters, respectively. These results suggest that the OWCZ is possibly thicker in the carbonate rock than clastic rock formations. The thickness of OWCZ in the clastic rocks changed from one part to another, depending on several factors including mineral composition, grain size, porosity, pore shape, and fluid type.
\end{abstract}

Keywords: Vp/Vs ratio, Porosity, Oil-water contact, Nahr Umr, Mishrif

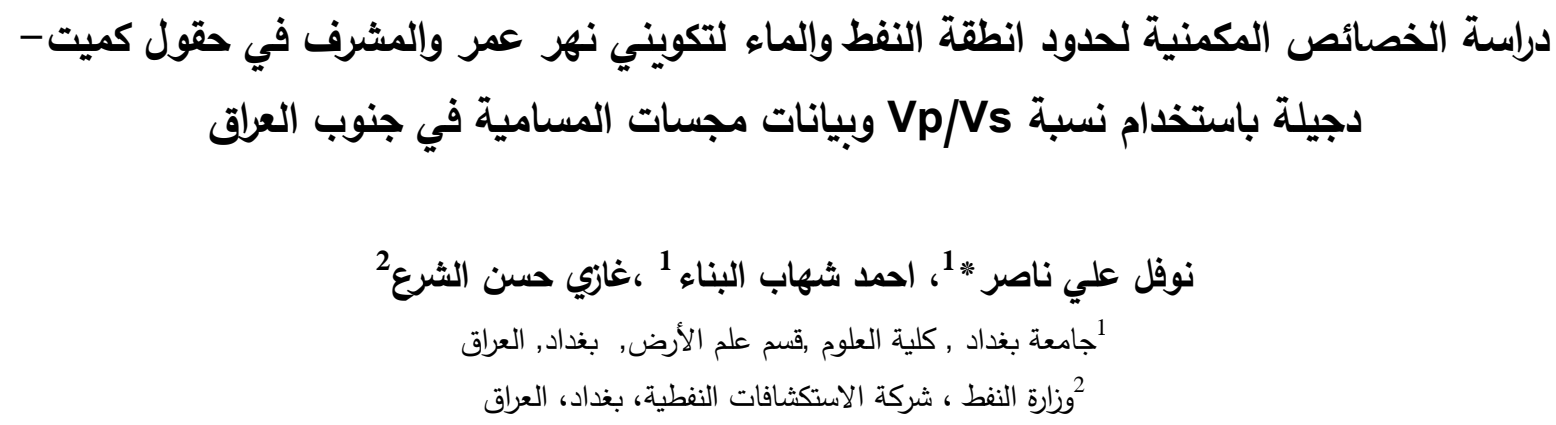

الخلاصه

تم استخدام البيانات التنصيلية لهجسات نسبة Vp/Vs والمسامية للكثف عن حدود منطقة التلامس

النفطي بالماء (OWCZ) لتكويني نهرعمر والمشرف ضمن حقول كميت والدجيلة في جنوب شرق العراق

وكانت نتائج الكثف عن حدود انطقة النفط مع الماء في هذه التكاوين من خلال دراسة مجسات P-wave ،

المقاومية ، والتثبع المائي والواقعة ضمن أبار كميت-1 و دجيلة-1، حيث وجد أن سكك منطقة تلامس النفط

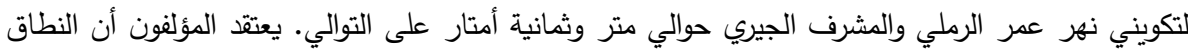

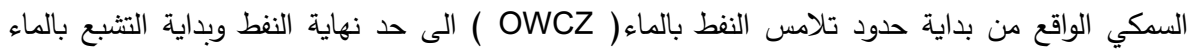

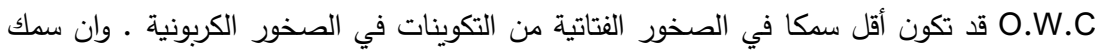

*Email: Nawfalalialabadi@gmail.com 


$$
\begin{aligned}
& \text { يتغير في الصخور الفتاتية من جزء إلى آخر اعتمادًا على العديد من العوامل بما في ذلك التركيب OWCZ }
\end{aligned}
$$

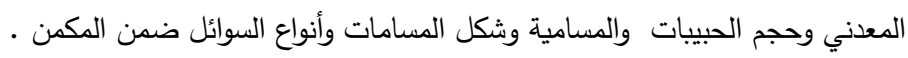

\section{Introduction}

The oil-water contact (OWC) is an important parameter to evaluate the petrophysical properties and calculate the volume of oil in the reservoir. The OWC does not reflect a sharp surface boundary, but it is a transition zone. The resistivity log is usually used to determine OWC and water saturation (Sw) [1]. The OWC identification depends on low resistivity contrast. Akbar and Permadi [2] believe that OWC which is determined using electrical logs is occasionally uncertain. The capillary transition zone in reservoirs depends on the pressure difference across the fluid contact [3]. Some authors believe that the thickness of the OWCZ changes during the production process [4]. Therefore, it is important to monitor the OWC continuously. The thickness of the OWCZ may vary among the different parts, ranging from 1 to 15 meters. OWC is parallel to the tectonic stress, but the actual situation shows that this contact is more complicated. Han and Batzle [5] found that the $\mathrm{Vp} / \mathrm{Vs}$ ratio is more sensitive to the change in fluid type. Thus, it can be used to identify the hydrocarbon contact. The $\mathrm{Vp} / \mathrm{Vs}$ ratio is used by many authors in lithology discrimination, degree of consolidation determination, and pore fluid identification $[6,7]$. The porosity of rocks is usually decreased with the increase of compaction, which is accompanied by an increase of burial depth. However, for sandstone rocks, the mineralogical and chemical factors are more significant than the physical forces [8]. Temperature and time influence porosity variation with the depth, mostly at shallow and moderate depths, whereas chemical agents and composition of the grains are more effective at depths more than three kilometers [9]. This study is concerned with the identification of OWCZ in Nahr Umr and Mishrif formations (Cretaceous age), particularly in Kt-1 and Du-1 wells, southern Iraq.

\section{Location and geology of the oil fields}

Kumait and Dujaila oil fields are located in Maysan governorate and northeast of Nasiriyah City, southeastern Iraq, as shown in Figure -1.

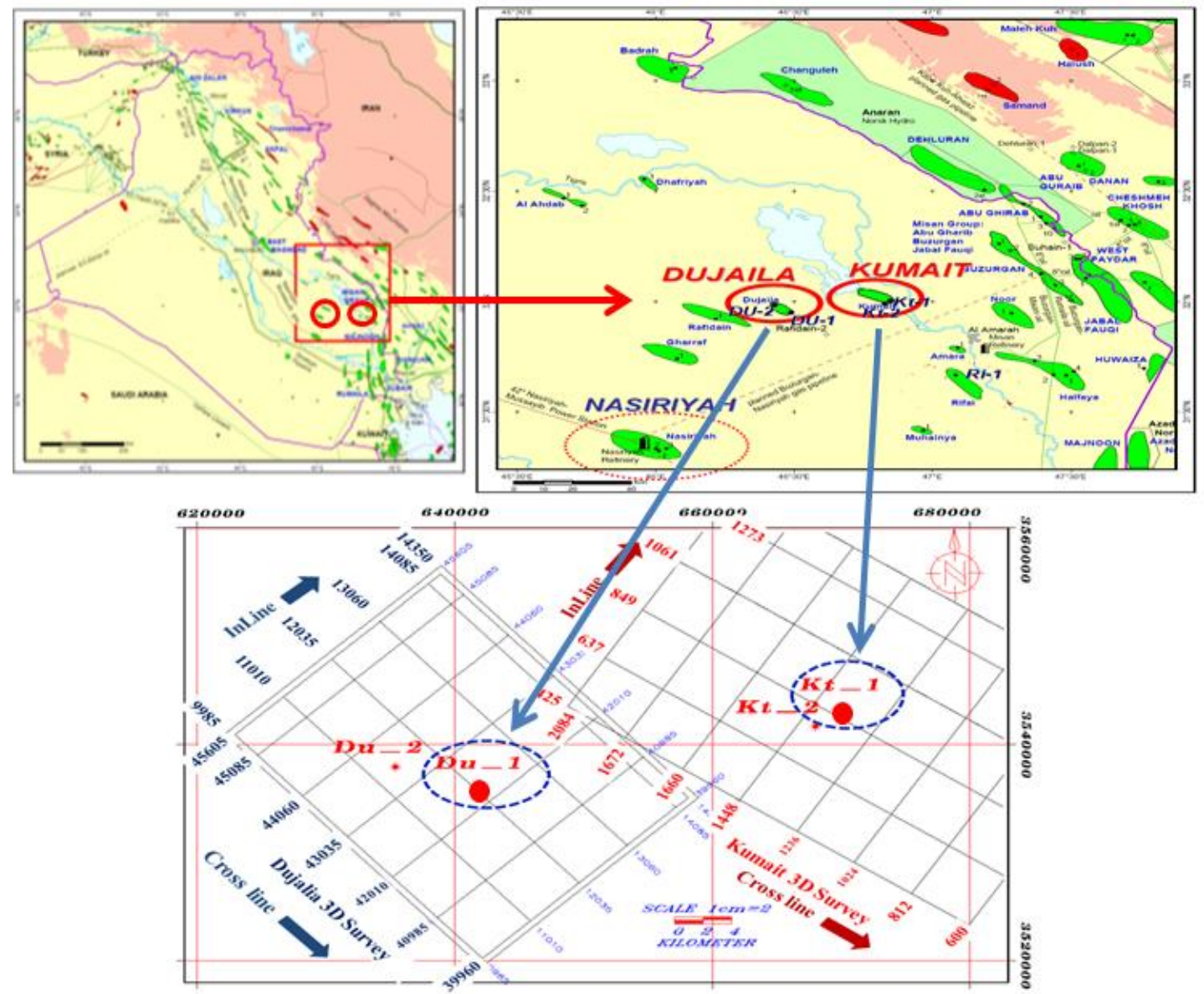

Figure1- Location and base map of the study area [10]. 
Tectonically, this area belongs to the Mesopotamian unstable subzone [11-13]. The Tertiary and Cretaceous stratigraphy columns in the study area are shown in Figures-(2) and (3), respectively. The Kt-1 well penetrated to a depth of $4410 \mathrm{~m}$. Nahr Umr sandstone formation (lower Cretaceous) is the main reservoir in Kumait Oil Field. This formation extended in depth from 3700 to $3840 \mathrm{~m}$ in Kt-1 well. The Du-1 well is penetrating to a depth of $4124 \mathrm{~m}$. The main reservoir in Dujaila oil field is Mishrif Limestone Formation (upper cretaceous). The upper contact depth of Mishrif Formation in Du-1 well is $2835 \mathrm{~m}$ and the lower contact depth is $3162 \mathrm{~m}$.

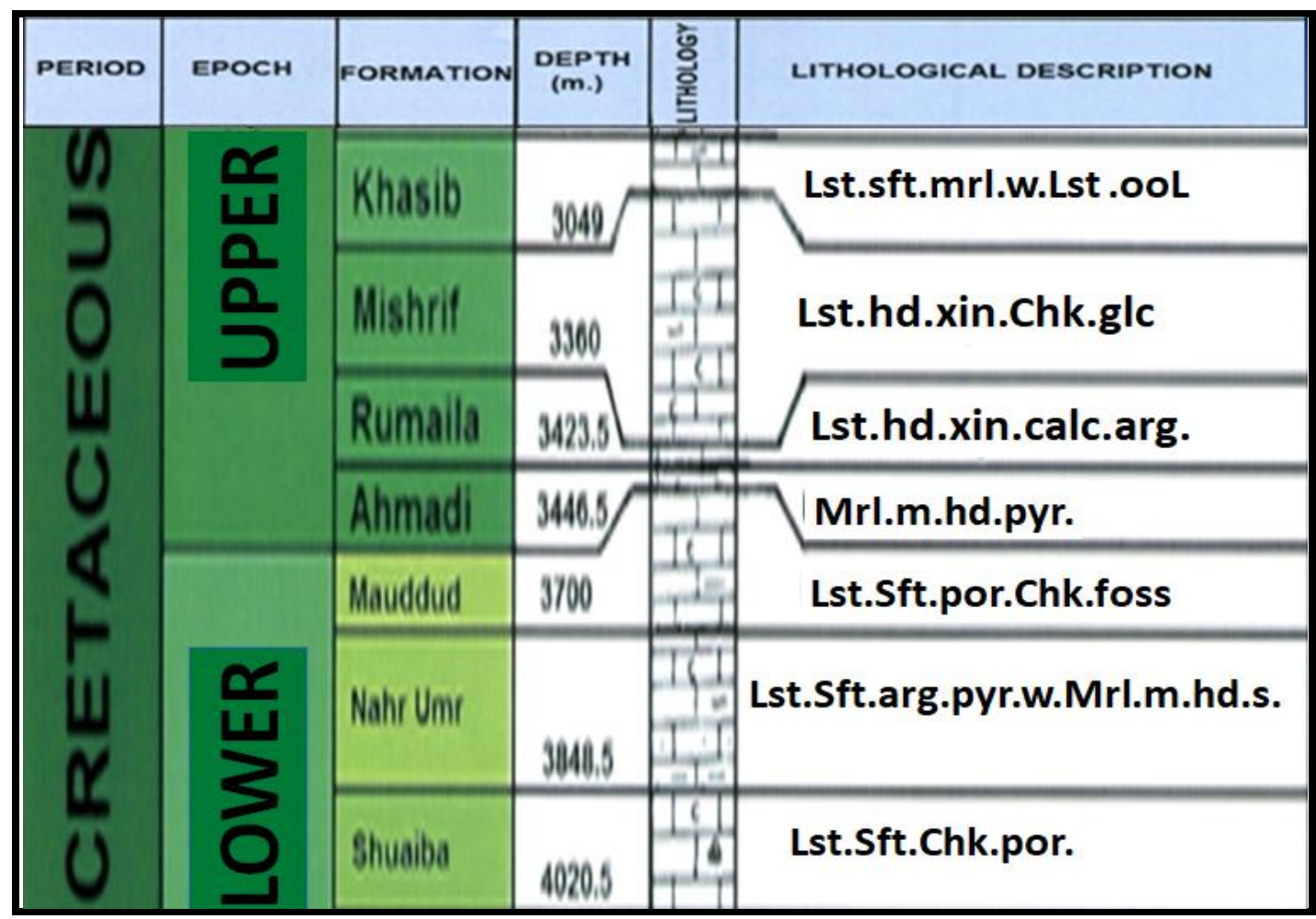

Figure 2- Geological column in Kt-1 well [14].

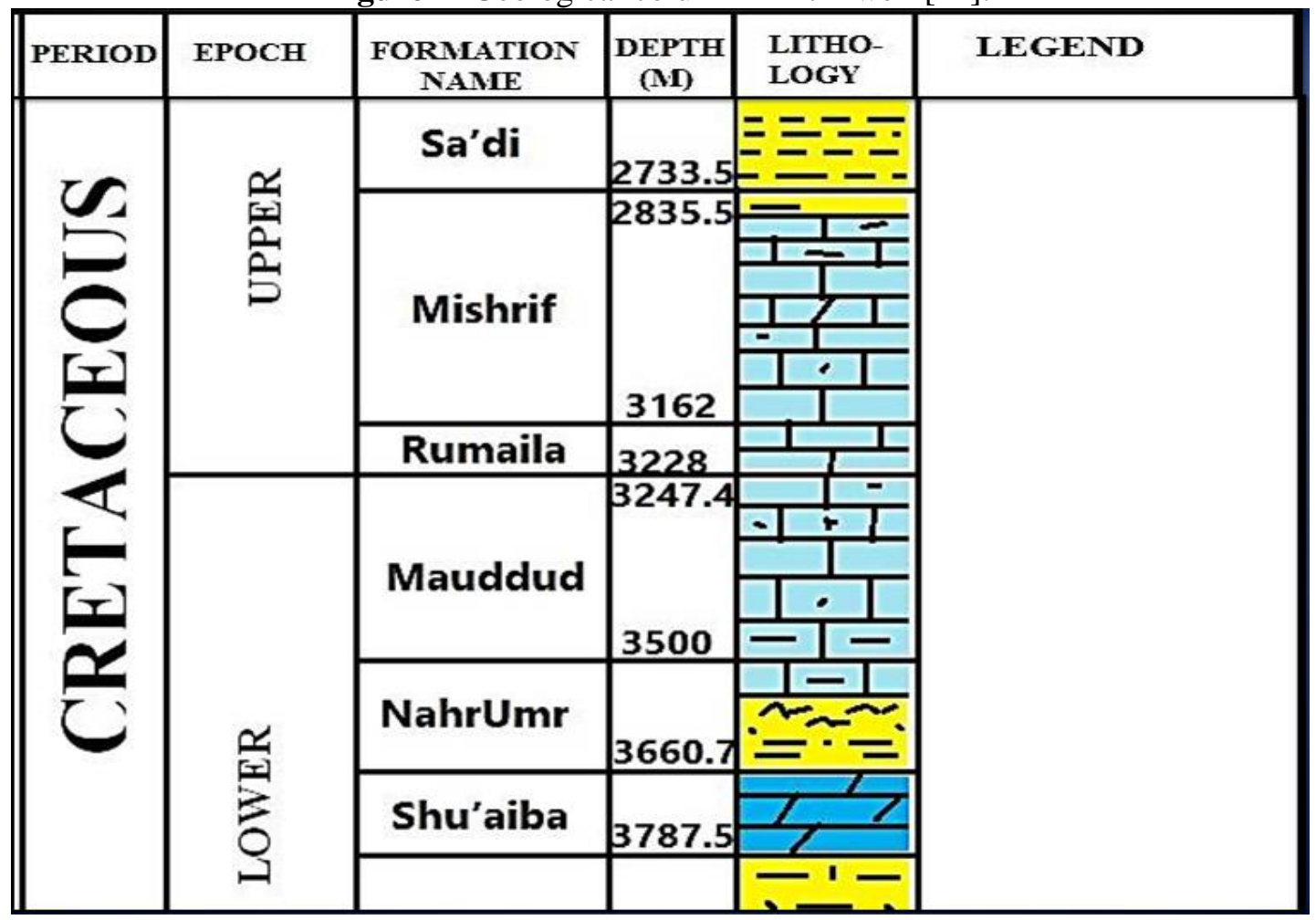

Figure 3 - Geological column in Du-1 well [15]. 


\section{Hydrocarbon-Water Contact analysis of Nahr Umr and Mishrif formations in both oil fields}

The resistivity logs are used to determine OWC and Sw. High contrast significant increase in the Sw values indicates the OWC [16]. Nahr Umr (Sand-2 layer) Sandstone Formation is the main reservoir in Kt-1 well. The well logs show that the sand-2 unit of this Formation is approximately 11 $\mathrm{m}$ in thickness at a depth between 3804 and $3815 \mathrm{~m}$. The values of P-wave and S-wave, obtained using Castagna's equation, density, Poisson's ratio, Vp/ Vs ratio and $\mathrm{Sw}$ logs of Nahr Umr Formation, are shown in Figure-4. The well logs of $\mathrm{P}$-wave, $\mathrm{S}$-wave, water saturation, volumetric shale, $\mathrm{Vp} / \mathrm{Vs}$ ratio, and effective porosity of the lower part of the reservoir of Mishrif Formation between the depths 28602900 are shown in Figure-5.

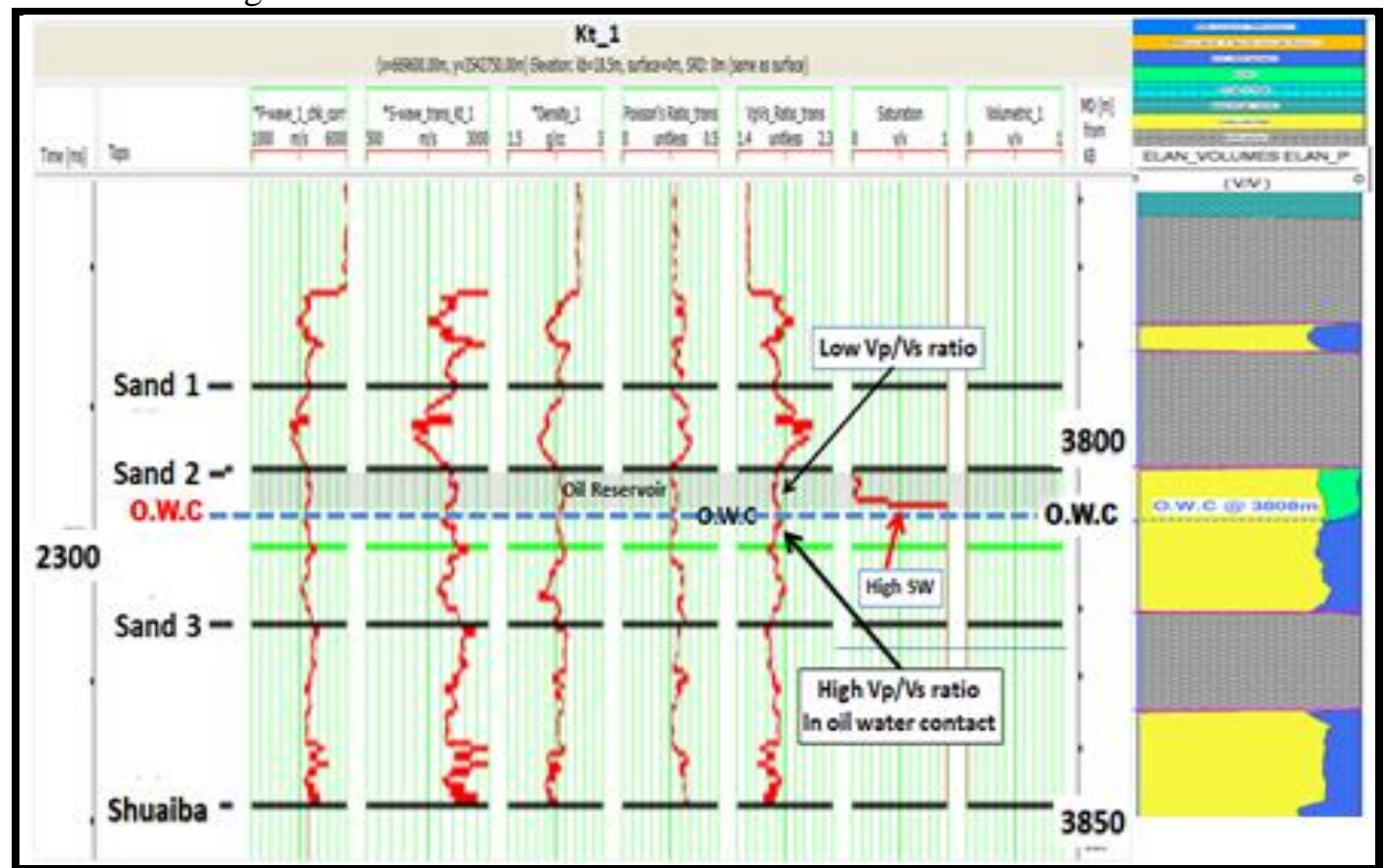

Figure 4- From left to right: Results of P-wave, S-wave, density, Poisson's ratio, Vp/Vs ratio, saturation, and volumetric logs for the Well Kt-1 and the level of Oil-Water contact in Sand-2 Unit within Nahr Umr Formation of Kumait Oil Field.

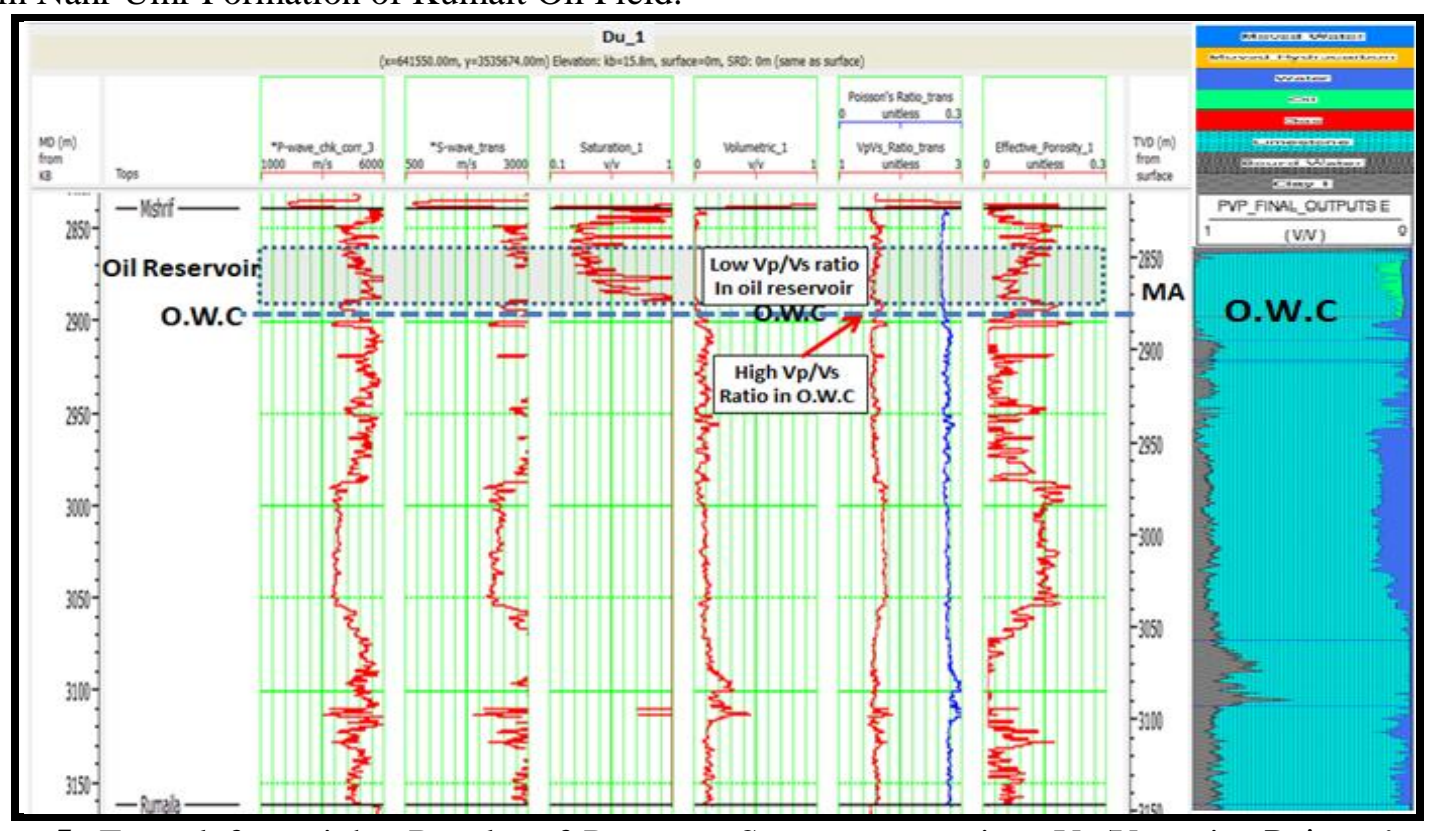

Figure 5- From left to right: Results of $\mathrm{P}$ - wave, S-wave, saturation, Vp/Vs ratio, Poisson's ratio, effective porosity, and volumetric Logs for Well Du-1 and the level of Oil-Water Contact in MA Limestone unit within Mishrif Formation of Dujaila Oil Field. 


\section{The usage of $\mathrm{Vp} / \mathrm{Vs}$ ratio and porosity logs to detect the OWC Zone}

$\mathrm{The} \mathrm{Vp} / \mathrm{Vs}$ ratio was reported to be changed at the OWC [6]. The $\mathrm{Vp} / \mathrm{Vs}$ and porosity logs are used in the present study to detect the OWCZ in the two selected wells. Three boundaries are established and shown in Figure-6. The first is the upper boundary (Green), at the level of 3804- $3807 \mathrm{~m}$ depth, indicates the starting oil zone (only oil). The second boundary (Red) at the level of 3807- $3808 \mathrm{~m}$ depth, represents the top of the OWCZ. The third boundary (Blue) at the level of $3808 \mathrm{~m}$ depth, indicates the lower boundary (the actual boundary) of the OWCZ. The three boundaries, which were traced by Vp/ Vs ratio log, were also traced by the porosity $\log$, as demonstrated Figure- 7 . The location of the detected boundaries coincides with the P-wave, resistivity, and Sw logs of Nahr Umr in Kt-1 well (Figure -8). The same above procedure is used for Mishrif Limestone Formation in Du-1 well of Dujaila oil field. The OWCZ was traced using the Vp/ Vs ratio and porosity logs, as illustrated in Figures-(9) and (10), respectively. The P-wave, resistivity, and Sw logs were employed to support the results obtained using Vp/ Vs ratio and porosity logs and confirm the detection of the OWCZ in Mishrif Formation (Figure-11).

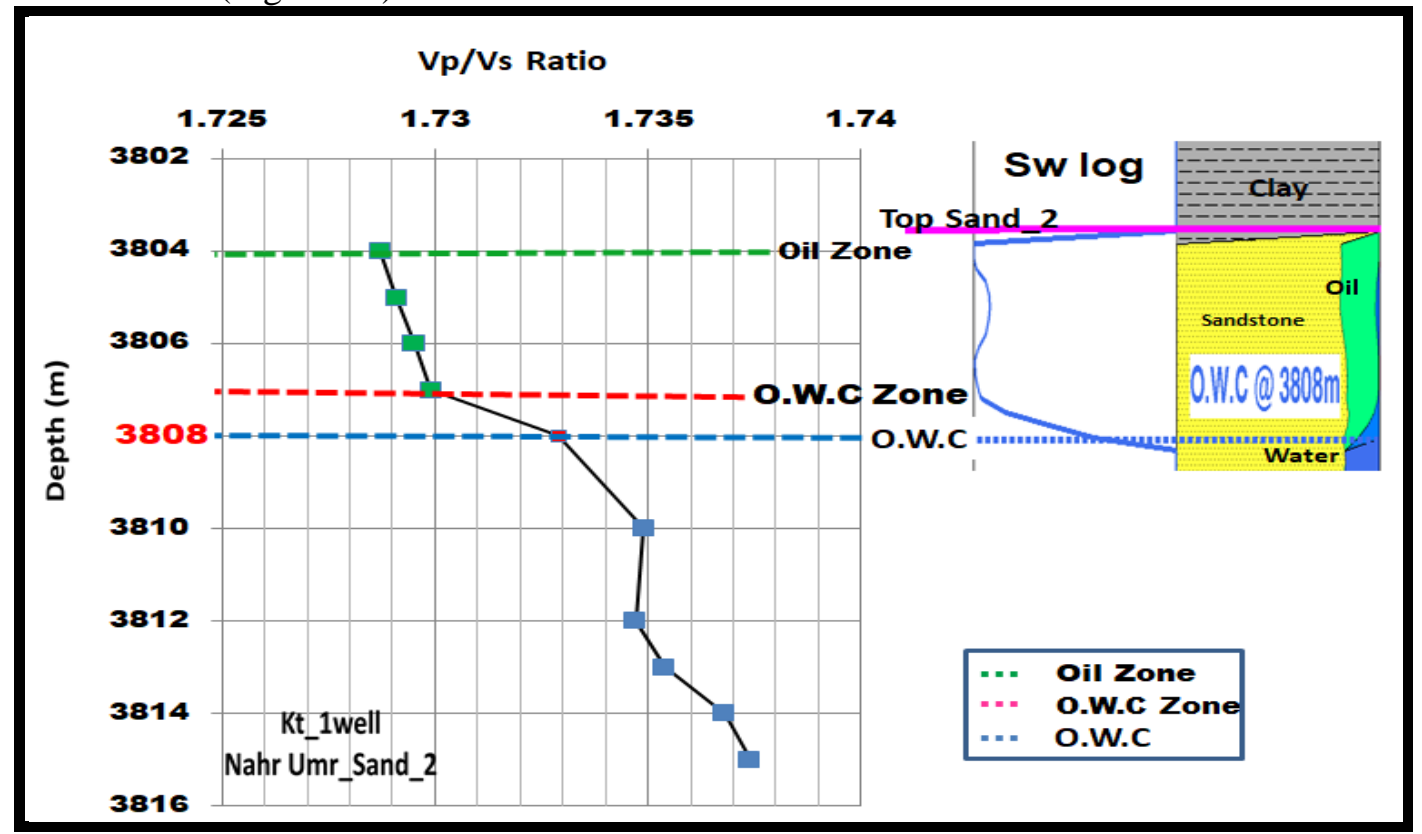

Figure 6 - Vp/Vs ratio log values in Sand_2 reservoir unit within Nahr Umr Formation.

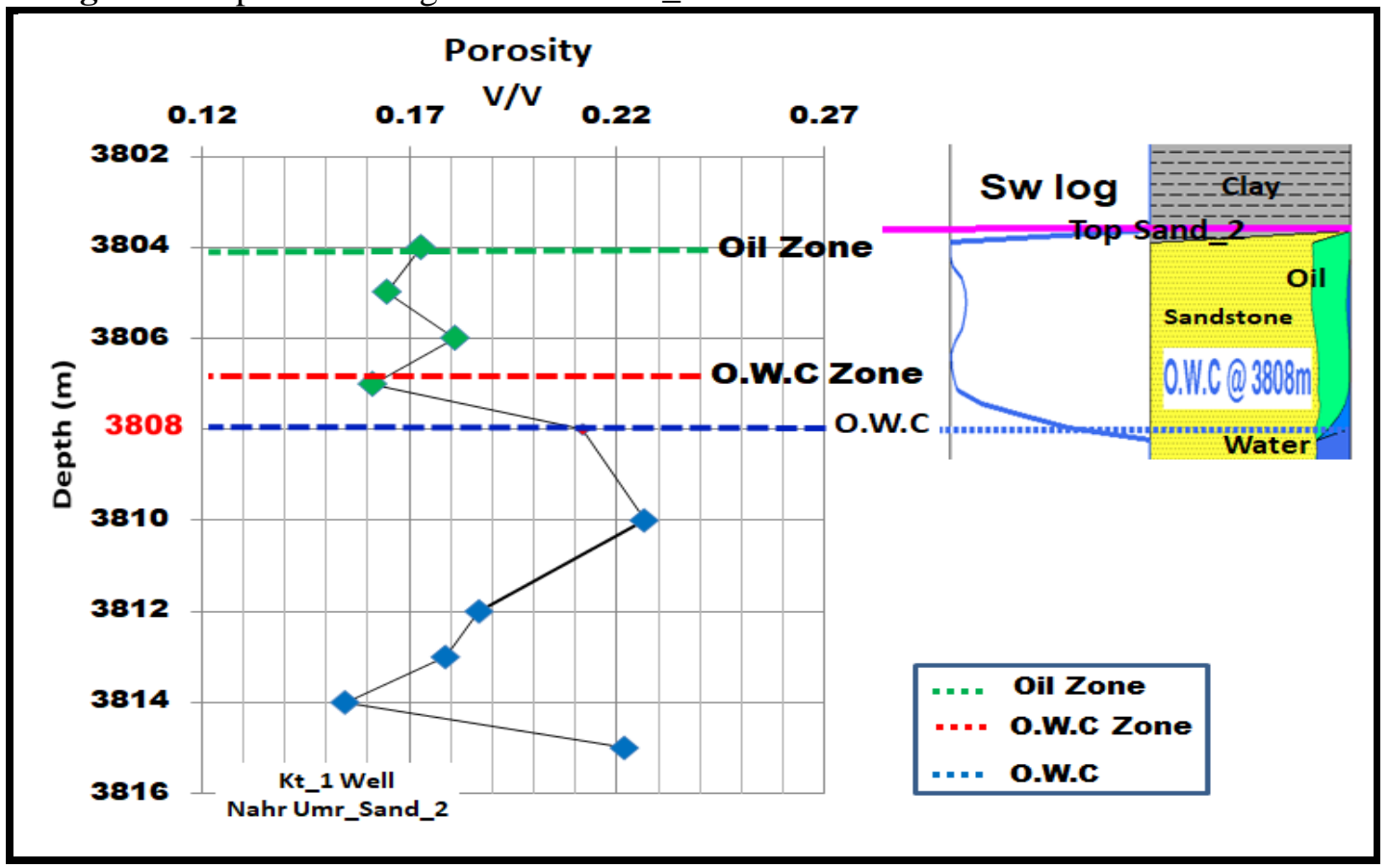

Figure 7- Porosity log values in Sand-2 reservoir unit within Nahr Umr Formation. 


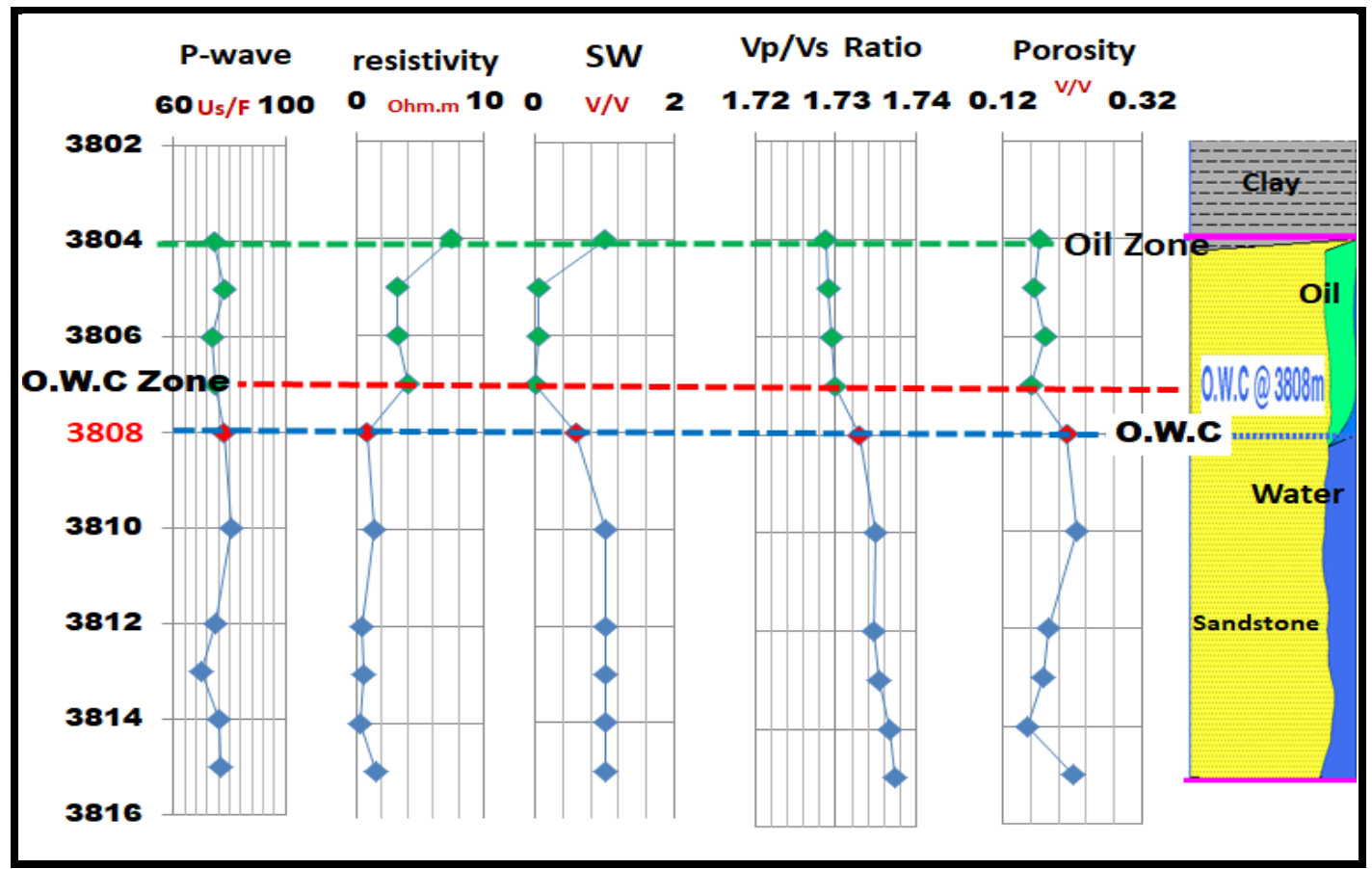

Figure 8- The relation between depth with $\mathrm{P}$-wave, resistivity, $\mathrm{Sw}, \mathrm{Vp} / \mathrm{Vs}$ ratio, and porosity in Sand2 reservoir unit within Nahr Umr Formation.

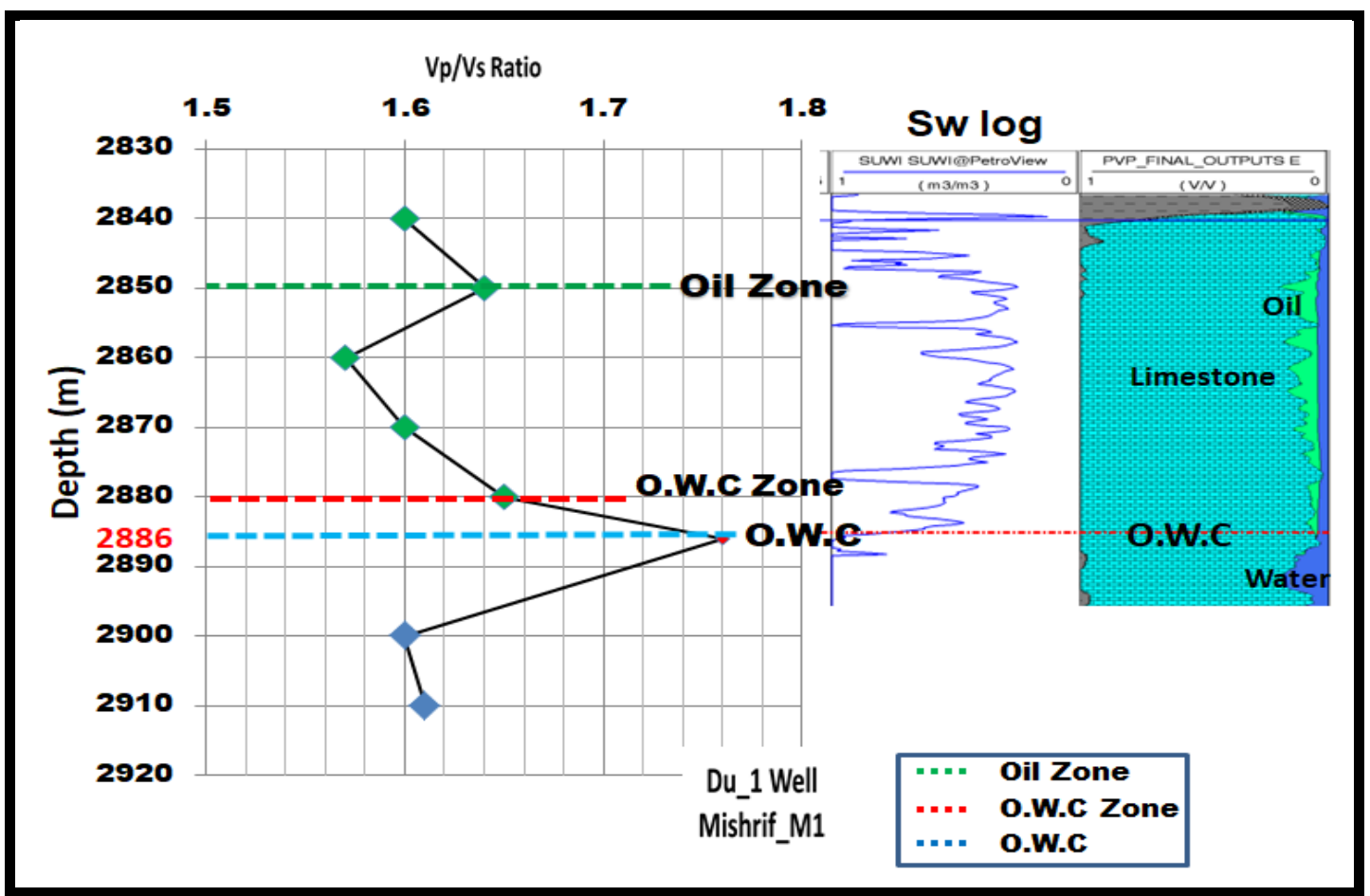

Figure 9- Vp/Vs ratio log values in MA (Limestone) reservoir unit within Mishrif Formation. 


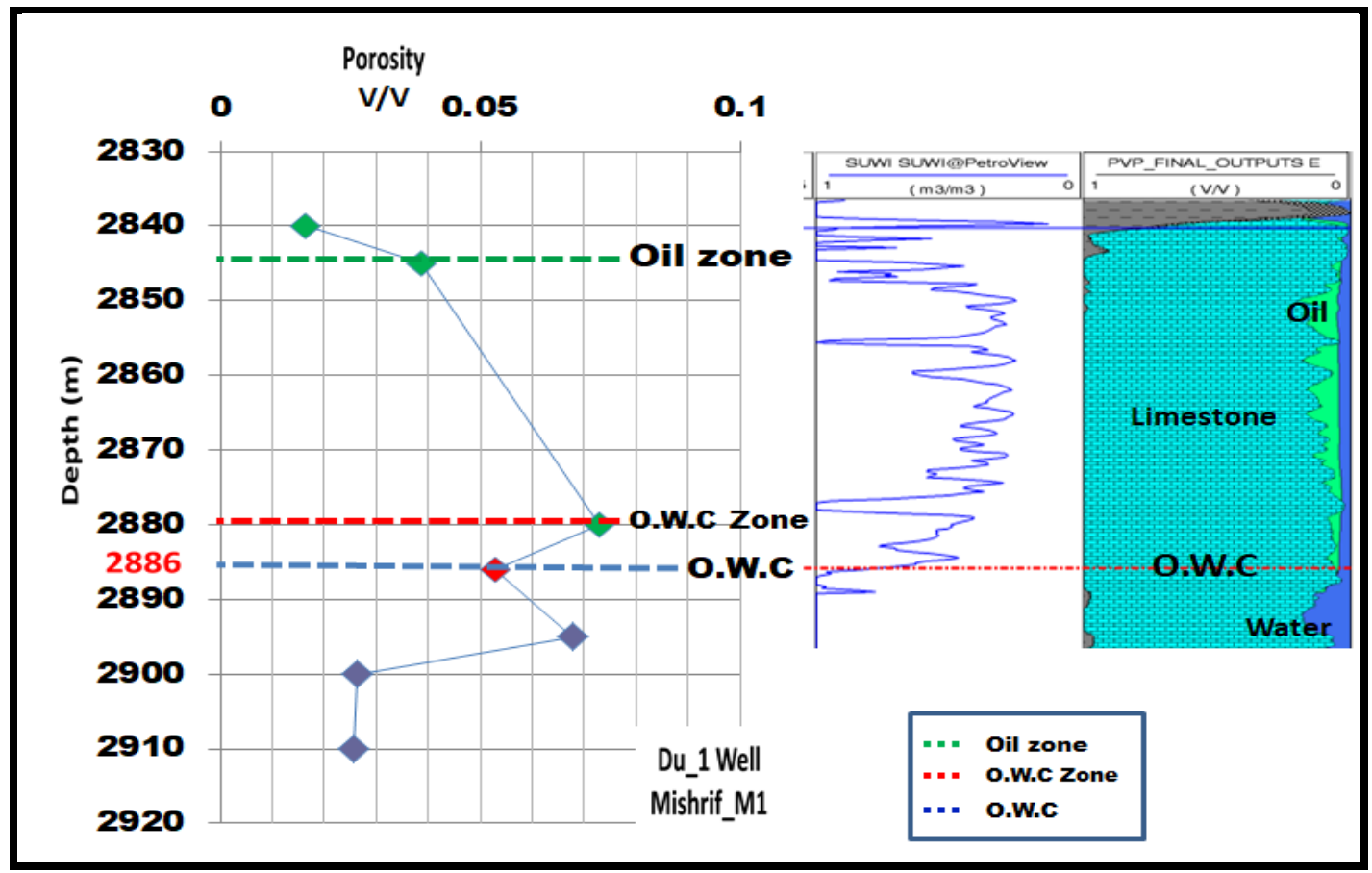

Figure 10- Porosity log values in MA (Limestone) reservoir unit within Mishrif Formation.

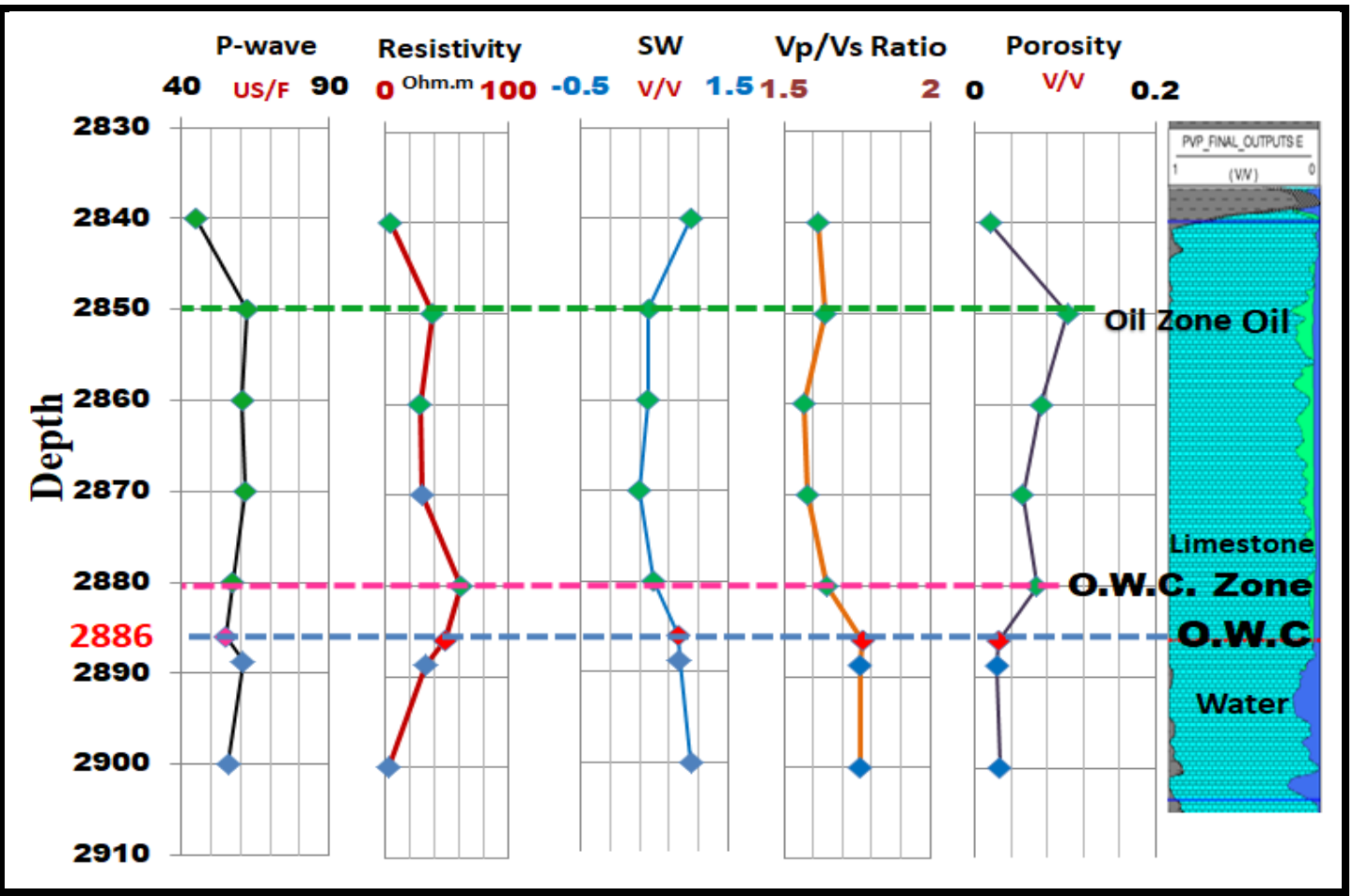

Figure 11- The relation between depth with P-wave, resistivity, $\mathrm{Sw}, \mathrm{Vp} / \mathrm{Vs}$ Ratio, and porosity in MA (Limestone) reservoir unit within Mishrif Formation.

\section{Conclusions}

It is concluded that the detailed study of the $\mathrm{Vp} / \mathrm{Vs}$ and porosity logs can be used to detect the actual location of the oil-water contact zone. Studying the logs data of Nahr Umr and Mishrif formations in Kt-1 and Du -1 wells of Kumait and Dujaila oil fields resulted in obtaining some important characteristics concerning the oil-water contact zone. It was found that the thickness of this zone in Nahr Umr sandstone Formation in Kt-1 well is approximately one meter. While the thickness of the oil-water contact zone in Mishrif Formation in Du-1 well reached eight meters. The authors believe that the oil-water contact zone may be thicker in carbonate rocks than clastic rocks. The 
difference in the thickness of this zone in clastic rocks may be dependent on mineral composition, grain sizes pore shape, and porosity.

\section{References}

1. Rasaq B. and Sikiru. 2016. Discrimination of reservoir fluid contacts using compressional and shear wave velocity. Global Journal of Pure and Applied Science: 22: 177-190.

2. Akbar A. and Permadi P. 2016. Estimation of fluid contact and transition zone: A case study of low contrast resistivity zone, International Petroleum Technology Conference 14-16 November, Bangkok, Thailand.

3. Al-Sudani J. A. 2014. Analytical model for detection the tilt in originally oil water contact.

4. Doerband R. 2013. Introducing a producible oil water contact (POWC) for better assessment of moveable oil in the transition zone, North Africa Technical Conference and exhibition, 15-17 April, Cairo, Egypt.

5. Han D. Liu J. and Batzle M. 2007. Acoustic property of heavy oil: measured data 76th Annual International Meeting, SEG, expanded Abstracts, 1903-1907

6. Rider M. 1996. The geological interpretation of well logs. $2^{\text {nd }}$ edition: whittles Publishing.

7. Hamada G. M. 2004. Reservoir fluids, identification using Vp/Vs ratio. Oil and Gas Science and Technology-Rev. IFP, 59(6): 649-654.

8. Magara K. 1980. Comparison of porosity depth relationships of shale and sandstone. Journal of Petroleum Geology: 3(2).

9. Ramm M. 1992. Porosity- depth trends in reservoir sandstones: Theoretical models related to Jurassic sandstone offshore Norway Marine and Petroleum Geology: 9(5): 553-56.

10. Al-Amri T. K., Al-Ekabi A. H. and al-Jawad S.N. 2014.Palynomorph stratigraphy, Palynofacies and organic geochemistry assessment for hydrocarbon generation of Ratawi Formation, Iraq. Arab J. Geoscience: 7(4): 1433-1455.

11. Jassim S. Z. and Goff. J. 2006. Geology of Iraq, Publisher Dolin, Hlavni 2732, Prague and Moravian Museum, Zelny trh 6, Brno, Czech Republic. 341p

12. Al-Banna A. S., Al-Sagri K. Z. , Humadi L. Z. 2013. The boundary between stable and unstable shelf in Iraq as inferred from using ideal gravity to elevation ratio), Arab. J. Geosci., Springer, 6: 187-191.

13. 13.Al-Banna A. S. and Ali K.K. 2018. The transition tectonic zone between the two parts of the platform in Iraq: A review study, Iraqi J. of Sci. 59(2C): 1086-1092.

14. Alwan, A.H., 2015. Evaluation Geological Study of Kumait Oil field. Geology and Geophysics in Oil Exploration, Baghdad, DC, Iraq.

15. Jassim, S.M ., 2013. Geological and geophysical study for 3D seismic survey in Dujaila Oil Field. Oil Exploration Company, Baghdad, DC, Iraq.

16. Bahremandi M. , Keramatil M. and Mirshahani M. 2010. Using Vp/Vs ratio to predict fluid type in oil reservoirs. Case study from an oil field southwest Iran Division of research studies, Institute of Petroleum industries (RIPI), Tehran, Iran. 